\title{
Exploring the linguistic landscape of Cameroon: Reflections on language policy and ideology
}

\author{
Martin Pütz \\ University of Koblenz-Landau \\ Landau, Germany
}

\begin{abstract}
This contribution focuses on the study of Linguistic Landscapes in the Central/Western African state of Cameroon, with particular reference to its capital, Yaoundé. Linguistic landscapes is a relatively recent area of research, and can be broadly defined as the visual representation of languages in public space. This paper will show that the field of linguistic landscapes can act as a reflection of linguistic hierarchies, ideologies and acts of resistance in multilingual and multicultural communities. At the same time, the sociolinguistic situation in the country will be investigated, which is paramount to understanding the linguistic and ideological conflicts between the anglophone minority and the francophone government. Cameroon's linguistic landscape will be explored via the various spaces that English, French, Pidgin English, Camfranglais and, to a minor degree, indigenous African languages occupy in its sociolinguistic composition. The methodological design is quantitative in nature, involving collecting more than 600 linguistic tokens (digital photos) in various public places mainly in and around the Cameroonian capital of Yaoundé. It will be demonstrated that the deployment of languages on signs and linguistic tokens, apart from serving informative and symbolic functions for the audiences or passers-by they target, also has social and political implications in an ethnically heterogeneous and linguistically hybrid society such as Cameroon. Whereas in some other former British colonies there are indications that the public space is being symbolically constructed in order to preserve some of Africa's indigenous languages (e.g. in Botswana, Rwanda, Tanzania), in Cameroon the linguistic landscape almost exclusively focuses on the dominant status and role of one single language, i.e. French, and to a lesser extent English, whose speakers therefore feel marginalized and oppressed by the French government.
\end{abstract}

Keywords: Anglophone problem, Cameroon, ideology, language policy, linguistic landscape, public space

\section{For citation:}

Pütz, Martin. 2020. Exploring the linguistic landscape of Cameroon: Reflections on language policy and ideology. Russian Journal of Linguistics 24 (2). 294-324. DOI: 10.22363/26870088-2020-24-2-294-324 
Научная статья

\title{
Отражение языковой политики и идеологии в языковом ландшафте Камеруна
}

\author{
Мартин Пютц \\ Университет Кобленц-Ландау \\ Ландау, Германия
}

\begin{abstract}
Аннотация
Статья посвящена изучению языкового ландшафта в африканском государстве Камерун с особым вниманием на его столицу — город Яунде. Языковой ландшафт - относительно недавняя область исследований, и ее можно в широком плане определить как визуальное представление языка в публичном пространстве. В статье показано, что языковой ландшафт может служить отражением языковой иерархии и идеологии, а также актов сопротивления в многоязычных и многокультурных сообществах. Проведено исследование социолингвистической ситуации в Камеруне, которая имеет первостепенное значение для понимания языковых и идеологических конфликтов между англоязычным меньшинством и франкоязычным правительством. Изучение языкового ландшафта Камеруна проведено с учетом социолингвистического состава изучаемого языкового пространства, которое представляют английский язык, французский язык, английский пиджин, так называемый Камфранглиш - смесь камерунских вариантов французского и английского языков и пиджина — и, в незначительной степени, коренные африканские языки. Материалом исследования послужили более 600 запечатленных на фотографиях языковых примеров, собранных в различных общественных местах, главным образом в городе Яунде и его окрестностях, которые были проанализированы с применением количественного анализа. В статье показано, что в этнически неоднородном и лингвистически гибридном обществе, каким является Камерун, языки, используемые на знаках и разного рода надписях, помимо выполнения информационных и символических функций, также имеет социальное и политическое значение. Если, как свидетельствуют факты, в некоторых других бывших британских колониях, например, в Ботсване, Руанде, Танзании, общественное пространство символически создается с целью сохранения некоторых языков коренных народов Африки, то в Камеруне языковой ландшафт ориентирован почти исключительно на доминирующий по статусу и роли французский язык и, в меньшей степени, на английский язык, носители которого чувствуют себя маргинализованными и угнетенными французским правительством.
\end{abstract}

Ключевые слова: проблема англофонии, Камерун, идеология, языковая политика, языковой ландиафт, общественное пространство

\section{Для цитирования:}

Pütz, Martin. 2020. Exploring the linguistic landscape of Cameroon: Reflections on language policy and ideology. Russian Journal of Linguistics 24 (2). 294-324. DOI: 10.22363/26870088-2020-24-2-294-324

\section{Introduction}

This paper presents the results of a piece of research on the multilingual repertoire displayed and exploited in the linguistic landscape (LL) of the Central/Western African state of Cameroon. It is intended to be a contribution to the rapidly growing field of research into Linguistic Landscapes, an emergent branch of macro-sociolinguistics and semiotics, which is generally perceived as the 
study of the visible (even multimodal) representation of multiple languages and images in a globalized urban environment. LL tokens in principle can be found in all quarters of the world where people (actors/authors) leave or have created visible and multimodal signs which communicate meanings and intentions in various ways, i.e. signposts; photographs and videos; billboards; public road and safety signs; slogans and commercials; lighting and printed materials; names of buildings, streets, shops and areas of major tourist attractions; instructions and warning notices and prohibitions; graffiti; tattoos; and signs in cyber space, etc.; the list is endless in essence, such signs are "live" documentations and reflections of the physical environment of the late-modern, urbanized space. To put it in a nutshell: this paper is concerned with the simple and straightforward research question as to "where (my emphasis) language is located in the public space" (Mooney and Evans 2019: 86).

To date in the field, there have been disproportionately few investigations into LL in African states. Specifically, sub-Saharan Africa is a substantial and heterogeneous part of a continent with conflicting and antagonistic policies and multifaceted landscapes in urban places. Most LL studies on African spaces deal with acts of resistance, periods of crises or so-called linguistic warscapes (McLaughlin 2015). Today, issues of language policy and the ideological significance of public signage with reference to the globalization of English (or any other global language such as French, Spanish, Arabic, etc.) is a theme which has attracted LL researchers focusing on multilingual and multimodal signage in, for example, African cities and even rural areas (Banda \& Jimaima 2015).

There are hardly any LL studies on Cameroon (a few will be discussed in section 3). The country is a linguistic melting pot and comprises over 283 national/indigenous languages (Eberhard, Simons \& Fenning 2019). As a result of colonization, French and English are the official languages of Cameroon. A policy of official bilingualism is enshrined in the state Constitution, very much to the detriment of indigenous languages. Despite the official equality of French and English, however, the French language has far more visibility in public space than English. This is an unequal situation which will be investigated by considering the multilingual LL and the ideologies that signs communicate in various public spaces of the city of Yaoundé (2.5 million population).

Due to the "Anglophone problem" (sometimes known as Ambazonia War), the socio-political situation in the country as of December 2019 is in serious turmoil. For more than three years (since October 2016), protests and strikes have escalated into a crisis over the economic, cultural and political marginalization of Cameroon's anglophone minority. In this period, the two anglophone regions (Southern Cameroons: North-West and South-West regions, see Fig. 1) have experienced general strikes, school boycotts and violence (for more on the Anglophone problem, see section 2.2). In this vein, the public space in streets and social institutions is not neutral territory, but is instead a negotiated and contested arena. 


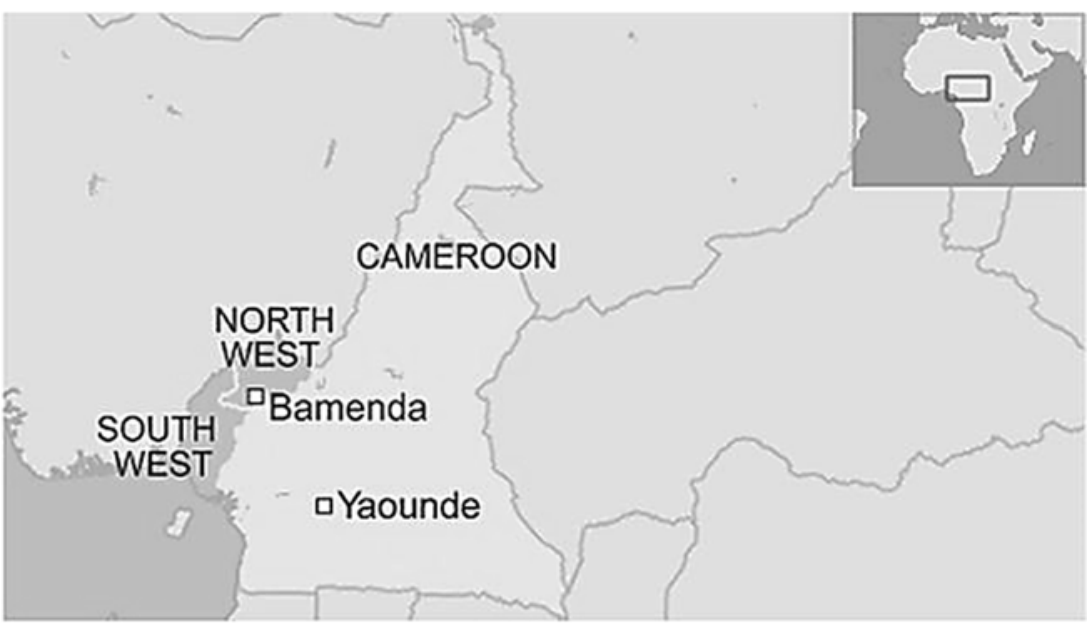

Fig. 1. The two Anglophone regions of North-West and South-West Cameroon (Southern Cameroons)

The paper is divided into four major parts. After a brief overview of the research paradigm of Linguistic Landscapes with occasional references to the Cameroonian situation (section 1), I will provide a socio-historical and ideological survey of Cameroon focusing on the colonial and postcolonial period with particular reference to language policy issues in Cameroon (section 2). The socalled "Anglophone problem" is evident in relation to linguistic and cultural issues and unfortunately as part of a tremendous ideological conflict which has characterized the political landscape of Cameroon up until the present day. The present case study will be introduced by a general discussion on LLs as researched in parts of Africa and a brief survey of earlier LL studies on Cameroon (section 3). Thereafter, an analysis will be presented of LLs in Cameroon and its capital Yaoundé (and in some parts of anglophone Limbe and francophone Douala). The monolingual and bilingual signage in the country will be discussed with reference to the status and role of languages/varieties, language policy and ideology. ${ }^{1}$ (section 4). Section 5, finally, contains a brief summary of the results and provides a research outlook.

\section{Linguistic landscapes, multimodality and discourses of place}

This study explores the manifestations and thematization of multilingual signage in the LL of the state of Cameroon. This involves identifying, collecting and interpreting the linguistic objects and tokens displayed and exploited in public places of the environment with a focus on the capital city of Yaoundé. Due to lack

${ }^{1}$ A work-in-progress report has been presented to an international audience of the World Congress of African Linguistics (WOCAL9 in Rabat, August 25-28, 2018), as well as the WestAfrican Languages Congress (WALC31 in Abidjan, August 12-15, 2019). Participants at these conferences have been generous with their ideas; likewise my students at ENS (Ecole Normale Supérieure, Université de Yaoundé I) and at Koblenz-Landau University have contributed with their feedback to the present paper. 
of space, the paper will not discuss the whole array of key terms and theoretical concepts prevalent in LL studies, ${ }^{2}$ but instead concentrates on multilingual signage in the state of Cameroon.

The aim of the study is to show that LL can provide valuable insights into the socio-historical, ideological and multilingual situation of Cameroon, including common patterns of language usage and official language policies. Specifically, power relations between different linguistic groups will be taken into account, an ideological issue which has led to enormous political conflict in Cameroon, especially during the past few years (see "Anglophone problem" in section 2.2.). Here, the LL acts as a "showcase to society" which, according to Schmitt (2018: 16), may reflect "social, political, economic, historical, linguistic, ethnic and religious movements of a society." Thus, through studying the LL of a community or neighborhood, researchers observe and identify the obvious ideologically and politically prevailing language(s), but can also locate indigenous or minority language presence in an area, as will be shown later in the paper in the case of Chinese (as well as Camfranglais and Pidgin English) in Cameroon.

\subsection{Definition of linguistic landscape}

The research area of LL studies is a relatively new and rapidly growing field of study. It was first mentioned in a seminal paper by Landry and Bourhis (1997) who discussed notions of ethnolinguistic vitality and attitudes toward language(s) in Quebec, Canada. LL is considered a new approach to multilingualism and sociolinguistics (in conjunction with anthropology, sociology, media studies, cultural geography, history, etc.) which emerged due to an increasing interest in linguistic diversity, language ecology and the era of internationalization and worldwide integration where people, languages and spaces interact in creating a global, but also local, environment in public places. Due to the fact that the LL is often studied in urban, multilingual areas, some scholars suggest that the terms "linguistic cityscape" or "multilingual cityscape" (Coulmas 2009: 14) would be more appropriate. In this vein, Pennycook and Otsuji (2015: 3) use the term "metrolingualism" in their attempt to understand linguistic resources in relation to the city, i.e. "to show how everyday multilingualism operates in markets, cafés, streets, shops and other social city spaces." Generally, linguistic commodification in tourism (Heller et al. 2014) also can be held accountable for such social spaces in society. ${ }^{3}$

\footnotetext{
${ }^{2}$ Here the reader is referred to Pütz and Mundt (2019b) who provide a comprehensive account of key terms and a discussion of LL studies published during the past 20 years (for an overview of themes, debates and future directions of LL, see Shohamy 2019 in the same volume).

${ }^{3}$ In terms of commodification, the Russian Journal of Linguistics (2017) is devoted to the topic of Linguistic Landscapes with a focus on "Language commodification of Russian". The contributions to this special issue consider commodification of the Russian language in different countries around the world. In this vein, viewed from an economic perspective, the LL-articles draw attention to motivations behind attempts to turn Russian into a 'valuable' communicative resource.
} 
The most frequently quoted definition in modern LL studies is the one provided by the Canadian scholars Landry and Bourhis (1997: 23) who refer to Linguistic Landscape as "the visibility and salience of languages on public and commercial signs." And further (1997: 25):

The language of public road signs, advertising billboards, street names, place names, commercial shop signs, and public signs on government buildings combines to form the linguistic landscape of a given territory, region, or urban agglomeration.

Certainly, signs in public space have been studied long before Landry and Bourhis' study (see Spolsky 2009, for a review). However, it was this piece of research (ethnolinguistic vitality in Quebec) that not only coined and defined the term, linguistic landscape, but brought about a renewed interest in the field for many years to come.

From a typological perspective, Landry and Bourhis (1997) furthermore divide signs in the LL into government signs and private signs, which were later conceptualized in terms of top-down and bottom-up approaches. Government signs (top-down) are linguistic tokens which are commissioned by the state or local government bodies and are professionally produced (e.g. road signs, public institutions, announcements, etc.). Private signs (bottom-up), on the other hand, include commercial and advertising signs and are often created by individual people; examples include shop signs or private business signs. Throughout LL studies, there is general agreement that language use in the LL falls into one of the two categories, i.e. top-down or bottom-up strategies, as summarized in Table 1 (Ben-Rafael et al. 2006: 14):

Table 1

Top-down and bottom-up categories and types of items (Ben-Rafael et al. 2006: 14)

\begin{tabular}{|l|l|}
\hline Category & \multicolumn{1}{c|}{ Type of item } \\
\hline Top-down & $\begin{array}{l}\text { 1. Public institutions: religious, governmental, municipal-cultural and educational, } \\
\text { medical }\end{array}$ \\
\cline { 2 - 2 } & 2. Public signs of general interest \\
\cline { 2 - 2 } & 3. Public announcements \\
\cline { 2 - 3 } & 4. Signs of street names \\
\hline \multirow{3}{*}{ Bottom-up } & 1. Shop signs: e.g. clothing, food, jewelry \\
\cline { 2 - 2 } & 2. Private business signs: offices, factories, agencies \\
\cline { 2 - 2 } & 3. Private announcements: 'wanted' ads, sale or rentals of flats or cars \\
\hline
\end{tabular}

Since it is not always easy and straightforward where to draw a line between top-down and bottom-up, Greene and Williams (nd.) prefer to think of it more as a cline or a continuum whose orientation points may shift in different contexts or domains, with varying degrees of how 'official' (top-down) and 'unofficial' (bottom-up) language usage may turn out to be (see Fig. 2).

According to Greene and Williams, this allows us to include things that are more complex to define, such as T-shirts, as LL items (see Fig. 3). These are 
designed and manufactured by a company, but the individual expresses a personal choice by wearing them. Certainly, the printed T-shirt remains a prominent form of communication in our contemporary LL, but there is hardly any research that has examined the linguistics or semiotics of this unique mode of communication (a notable exception is Caldwell 2017). Their appearance in the urban landscape has both top-down and bottom-up influences, as can be seen by way of the following LL items taken in a street (left) and in a shop (right) in Yaoundé. Reh (2004: 3) refers to LL items such as T-shirts, newspapers or books as movable in terms of the spatial mobility of the objects inscribed, i.e. to what extent these are physically fixed.

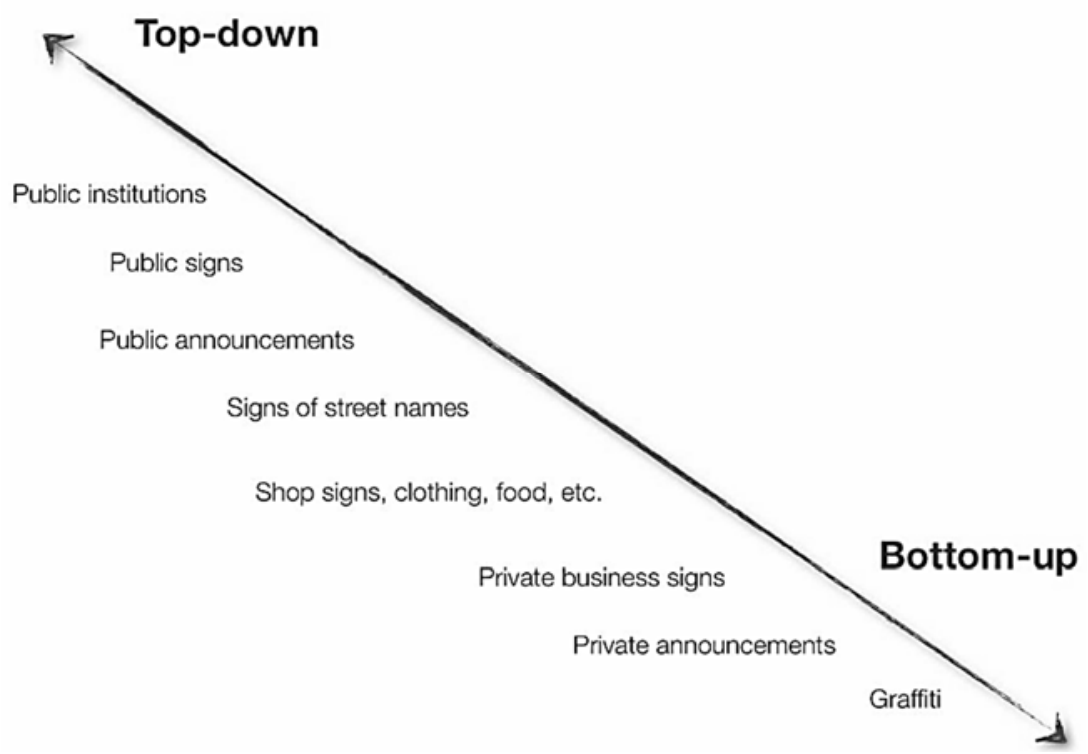

Fig. 2. Continuum of top-down and bottom-up signage categories (Greene \& Williams nd.)
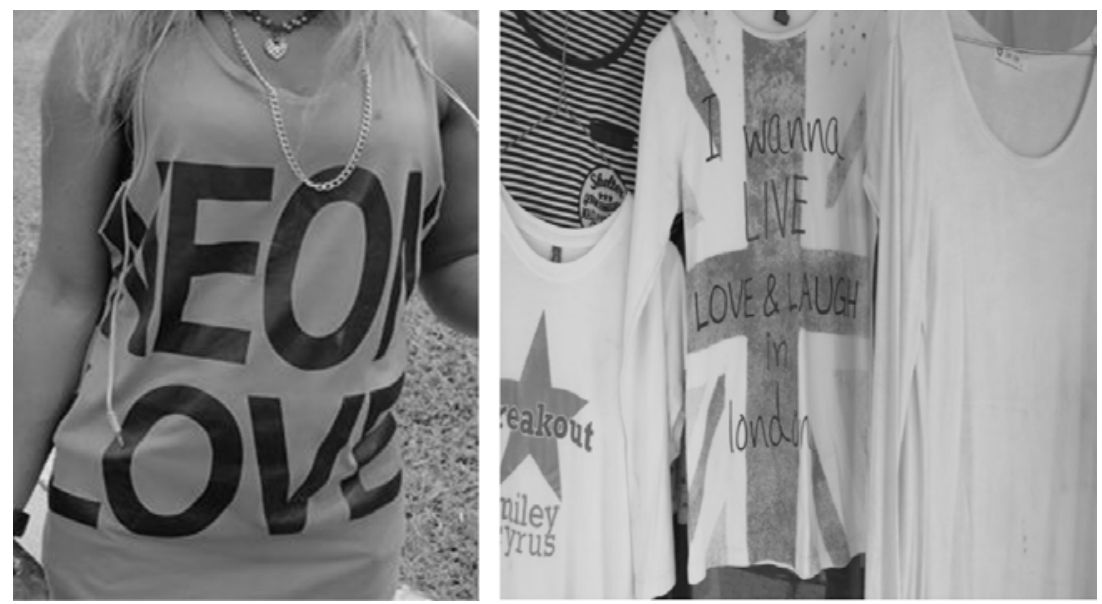

Fig. 3. T-shirts illustrating top-down (company) and bottom-up (personal choice) categories

We will later on see how private signs (as opposed to official ones) indeed display more freedom in choosing linguistic tokens as part of the LL in Cameroon. 


\subsection{Informative and symbolic functions of the linguistic landscape}

In their article, Landry and Bourhis (1997) make reference to two essential properties of the LL design, namely the presence of "informational and symbolic functions as a marker of the relative power and status of the linguistic communities inhabiting the territory" (1997: 23). The informational function of the sign is the basic message it conveys and thus uses language as a means of communication. It is primarily associated with top-down signage on, for example, administrative buildings or educational institutions, which may indicate the borders of the territory of linguistic groups. In this vein, the status, use and LL display of Cameroon's two official ex-European languages, French and English, is regionally distributed across the country and representative of the current political situation. Accordingly, the visibility of a language on publicly displayed signage is vital for its perceived ethnolinguistic vitality and ideological significance.

The symbolic function, on the other hand, appeals to the emblematic significance of the language(s)/varieties concerned. It refers to the value and status of the languages as perceived by the members of a language group in comparison to other languages in the vicinity. Principally, the symbolic function of LL has important repercussions for endangered languages, minority languages and multilingual illiterate societies, as is found, for example, in the case of Cameroon. LLs reveal deeper symbolic meanings which can point to language policy, language imperialism, marginalization, discrimination and even linguistic genocide (Phillipson 2012). It is also important to note that whatever language is most dominant in the LL automatically motivates a message that that language has strength, power, status, significance and vitality in the area. In contrast, languages that have little or no presence in an area are devalued and marginalized, and are seen as having little use in public affairs (Dagenais et al. 2009).

Setting aside the overwhelming status of French in a large number of societal domains, English in the Cameroonian LL is both informational and symbolic: while retaining its role as a medium of modernity, globalization and internationalization (symbolic function), it is used to provide different kinds of information, to tourists and also to locals, all of whom can speak English to a certain degree of proficiency (informational function).

\subsection{Multimodality: semiotic and geosemiotic landscapes}

Landry and Bourhis' definition has certainly become established as standard by many researchers and LL authors. However, as the field grows, more questions are raised about what constitutes or defines a sign, the languages in which they are written, who produced them (sign instigators/designers), to whom they are directed (sign viewers/recipients) and how signs are displayed and interpreted by the audience. In addition, more recent research attempts to define and understand more aspects of the LL by making reference not only to language(s), texts and words, but also to images/photos, etc., thus suggesting a multimodal approach to LL analysis (Shohamy \& Gorter 2009: 1): 
It is the attention to language in the environment, words and images displayed and exposed in public spaces, that is the center of attention in this rapidly growing area, referred to as linguistic landscape (LL)... It posits that LL is a broader concept than documentation of signs; it incorporates multimodal theories to include also sounds, images and graffiti.

Jaworski and Thurlow (2010) suggest a semiotic perspective to emphasize the way in which written discourse interacts with other discursive modalities like "visual images, nonverbal communication, architecture and the built environment" (2010: 2). Similarly, Barni and Bagna (2010) refer to a "critical turn" in LL, proposing that linguistic signs/tokens are to be seen as situated in sociocultural and historical space, thereby giving LL actors (both instigators and recipients) a more significant and active role in LL analysis and interpretation. Consequently, the LL locates meaning not just in language but in the richness, complexity and dynamics of the experienced world, about how we emplace language in concrete physical instances. By the same token, Scollon and Scollon (2003) put forward the notion of "geosemiotics" or "discourses in place" to do justice to the key interface between semiotics and the material universe, in other words the ways we analyze and interpret language as it is materially placed in the social and physical world that surrounds us (Scollon \& Scollon 2003: 19):

Geosemiotics considers 'non-semiotic' spaces where signs are prohibited as well as semiotic spaces which facilitate pictures, discourses, or actions... we all live our lives here on the earth and the central thesis of geosemiotics is that exactly where [my emphasis] on earth an action takes place is an important part of its meaning. It should not be surprising, then, that the 'natural' world is a central aspect of geosemiotics.

In other words, where a sign is placed tells us something about its underlying meaning and the possible intentions of the sign instigators. This geosemiotic account of the LL is also more in line with a view toward "expanding the linguistic landscape" (Pütz \& Mundt 2019a) by assuming a perspective on semiotic signage and multimodality whereby images, photos, sounds (soundscapes), nonverbal communication and movements, music, smells (smellscapes), graffiti, clothes and online communication can all be subsumed under one single multimodal umbrella. These semiotic tokens describe communication practices in terms of the "textual, aural, linguistic, spatial and visual resources — or modes — used to compose meaningful messages" (Pütz \& Mundt 2019b: 5). To put it in a nutshell: all linguistic and semiotic landscapes can be seen to create and generate meaning.

\section{A socio-historical and politico-ideological survey of Cameroon}

The following brief account of the historical development and political evolution of Cameroon is mainly based on Echu (2003). During the past 550 years, Cameroon has witnessed quite a large number of different invasions and annexations by European powers and imperial administrations. The Portuguese 
were the first Europeans to arrive in Cameroon and to enter the coastal waters of Cameroon in the early 1470s. Thereafter, like most African territories, Cameroon was invaded and exploited by a number of foreign European powers, e.g. first by the imperial German government when Cameroon became a German protectorate from 1884-1916 with a capital first at Buea and then at Yaoundé. Generally, the acquisition of African territories by European powers was internationally recognized at the Berlin Conference (also named Congo Conference) of 1884/85. With the defeat of Germany in 1916 during the First World War, Cameroon was divided between Britain and France, and administered under the League of Nations mandate. In 1960, French Cameroon gained independence from France and in 1961, the formerly British Southern Cameroons followed suit and joined with French Cameroon to form the Federal Republic of Cameroon, a date which is now observed as Unification Day, a public holiday. On May 20, 1972, a unitary State made up of seven provinces was created. Later in 1984, the number of provinces was increased to ten administrative regions through a Presidential decree, two of which are English-speaking (20\%) and eight French-speaking (80\%).

\subsection{Language policy in Cameroon}

The Constitution stated that French and English were supposed to be the official languages in Cameroon (1972/1996 Constitution; section I.1.3):

The official languages of the Republic of Cameroon shall be English and French, both languages having the same status. The State shall guarantee the promotion of bilingualism throughout the country. It shall endeavour to protect and promote national languages.

The 1996 Constitution of Cameroon proclaims French and English as the two official languages and, as far as indigenous (or national) languages are concerned, the Constitution only states that they will be "promoted" and "protected." But, in effect, indigenous African languages are marginalized to a large degree. Since its independence in 1960/61, Cameroon has adopted and adhered to an exoglossic language policy, i.e. none of its 283 indigenous languages plays a role in vital domains of official language use at the national level such as education, administration and politics. Instead, Cameroon has installed the imported languages of its former colonial masters, French and English, as official languages. In other words, this official exoglossic bilingualism is the outcome of Cameroon's colonial past (Kießling 2005).

Regarding the implementation of the policy of official language bilingualism, there is a clear imbalance in the use of the two languages as French continues to be the dominant means of communication while English is relegated to second place within the State. The frustration that arises within the anglophone community has led in recent years to the birth of anglophone nationalism, a situation that seems to be widening the gap between the two main communities of the society (anglophones and francophones), thereby compromising national unity (Echu 
2003: 31). Even when we compare the administrative provisions in terms of French and English LL emplacement, the policy prescribes that both languages are supposed to be balanced:

Posters, billboards, signs and notices of services or property of the State and the use of these shall be in both official languages on the same medium or on two separate media placed side by side so that the text in each language should be visible, apparent and available (Constitution of the United Republic of August 26, 1972 orders).

While the two official languages of colonial heritage dominate public life in the areas of education, administration, politics, mass media, publicity and literature, both the indigenous languages and the lingua franca Cameroon Pidgin English (CPE; likewise Camfranglais) are relegated to the background. As will be shown by illustration of the LL in Cameroon, there is a clear preponderance of the French language in comparison to English.

\subsection{The Anglophone problem}

17 years ago, Eko (2003) traced the role of the Cameroonian English-language press in creating awareness of the "Anglophone problem," and putting it on the Cameroonian and international political agenda. The anglophone community has, through its representatives, academics and media (foremost newspapers and radio programs), given an indication that it considers itself a marginalized minority of second-class citizens in the country of Cameroon. As Eko (2003: 79) points out, some of the more radical anglophone political activists consider Southern Cameroons, the English-speaking region of Cameroon, to have been recolonized by the French-speaking "République du Cameroun." Anglophones have long complained that their language and culture are marginalized. There is a widespread feeling in the anglophone region that reunification with francophone Cameroon in 1961 has led to a growing downgrading of the anglophone minority, endangering its cultural heritage and identity. Gradually, this created an anglophone consciousness: the feeling of being "marginalized," "exploited" and "assimilated" by the francophone-dominated state. Sadly enough, the situation culminated in October 2016 when anglophone teachers and lawyers took to the streets and protested against the French oppression. In response, the military arrested anglophone leaders (so-called separatists), blocked the internet for three months and installed a curfew in a series of repressive measures that became deadly when quite a number of people were killed during massive demonstrations. In 2017, the Cameroon Anglophone Civil Society began Operation Ghost Town, a call for the shutdown of schools in the English-speaking South-West and North-West provinces. According to the UN, the fighting has forced an estimated 20,000 Cameroonians to flee to neighboring Nigeria. In other words, Cameroon, a country previously known as politically stable, has been facing violence and serious human rights abuses from the days of colonization up until the present day. 
The following emplacements in English only (Fig. 4), photographed in the South-Western town of Buea, illustrate the linguistic and cultural conflict that has recently arisen between the anglophone separatists and the French government.

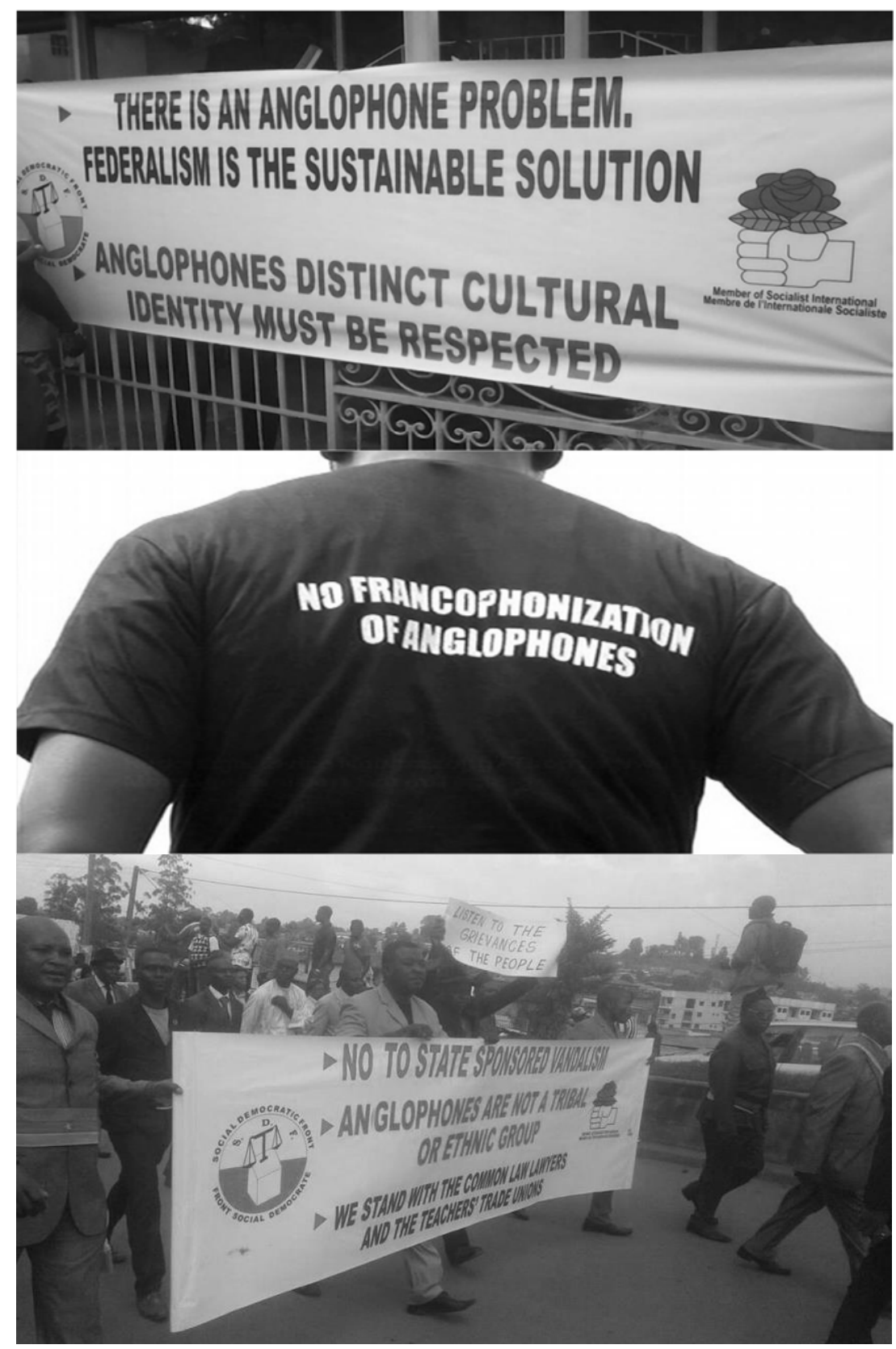

Fig. 4. English emplacement in Buea illustrating the Anglophone problem

\section{Linguistic landscapes of Africa and earlier LL studies on Cameroon}

Generally, research on Africa has largely been underrepresented in LL studies (especially compared to Europe and Asia). Most studies on sub-Saharan African 
spaces deal with acts of resistance and periods of crises when it comes to language policy, ideology, power constellations and the (in)visibility of minority or local (autochthonous) languages (e.g. Blackwood et al. 2016; Juffermans 2015; McLaughlin 2015; Rubdy \& Ben Said 2015; Woldemariam \& Lanza 2012). Also, LL studies carried out in the state of Cameroon are very rare. In their article on "Linguistic inequality in Cameroon," Nkamta \& Ngwenya (2017) deplore the fact that indigenous languages in the city of Douala are marginalized to a large extent, something which is most evident in the field of advertising as part of the overall landscape. Leaving out indigenous African languages in advertising and commercialization, among other things, denies many Cameroonians access to information and knowledge in their vernaculars, along with opportunities to participate in higher-level, formal discourses of advertising. While advertising is certainly an area where African languages have more or less been ignored to the advantage of the two official languages, French and English, it is yet another vernacular or lingua franca, i.e. Cameroonian Pidgin English (CPE or Kamtok), which calls for the recognition as an official language.

A further study (Abongdia \& Foncha 2017) explores the linguistic tokens of the University of Yaounde, ${ }^{4}$ in and outside of the main building, and shows how the language ideology and political regulations of an institution are reflected in its landscape (placards, signs, billboards, noticeboards, posters etc.). The paper also argues that there is a mismatch between the policy put in place and actual practice. The LL of an institution or community should be an actual representation of the people's language practices and consequently should coincide with the language policy put in place (which, according to their research, however, does not hold true for the University of Yaoundé). Finally, Makoudjou \& Mekamgoum's (2019) paper also explores and describes the LL of Yaoundé, namely the inscriptions of ten neighborhoods where more than 800 photos were collected. The authors found out that although government signs are mostly bilingual as stipulated by legal texts, French seems to be more prominent than English. Hybrid dialects like Pidgin English and Camfranglais, some Asian and other European languages are likewise present in the community. Local languages appear very scarcely and, if so, only in the domain of food.

\section{Linguistic diversity and cityscapes of Cameroon: An LL analysis}

The discussion will now turn to a brief outline of the methodology and data collection procedure before focusing on the extent to which the various linguistic tokens (billboards, posters, etc.) reflect the government's alleged balance between French and English in Cameroon's capital, Yaoundé. As well as discussing the excolonial languages (English, French) and their roles and statuses in the cityscapes (Coulmas 2009) of the country, reference will also be made to some of the linguistic

${ }^{4}$ In 1993, following a university reform, the country's oldest university, the University of Yaoundé, split into two separate entities: the University of Yaoundé I and the University of Yaoundé II. Our main concern will be with the former institution, i.e. the University of Yaoundé I. 
signs and tokens which relate to Cameroon's overall sociolinguistic profile (Cameroon Pidgin English, Camfranglais, local and minority languages).

\subsection{Methodology, data collection and sociolinguistic profile}

Approximately 600 digital photos were taken in and around the capital of Yaoundé in public and private spaces: signs issued by public authorities (government, municipalities, public agencies, schools, universities, etc.) on the one hand, and on the other hand, signs issued by individuals, associations or firms acting more or less autonomously within the limits authorized by official regulations (shops, private companies, department stores, etc.). The focus was clearly on tokens which illustrate the discrepancy between language policy (de jure status) as implemented by the Cameroonian government (co-official French and English bilingualism) and the de facto status which, however, reveals a clear preponderance of French signs, thereby aggravating the Anglophone problem (cf. section 2.2.).

The analytical tool for the analysis of linguistic tokens involved a number of coding categories which, for example, show how the languages/varieties appear on the signs, the location of the signs, the font size, the number of languages used on each sign, the order of languages on bilingual or multilingual signs, codeswitched or codemixed items, the presence of proper names, aspects of translation and the amount of information given (morphology, syntax, semantics, pragmatics), etc.

The main survey was carried out in 2016 (additionally, several related research trips to Cameroon were made between 2012 and 2016) and was conducted in six different regional districts of Yaoundé: (i) the administrative center (headquarters of government institutions), (ii) la Cité Verte (residential area), (iii) Mokolo (busy industrial quarter and the great market Marché Mokolo), (iv) Melen (touristic area, hotels), (v) Bastos (foreign embassies and expatriate communities) and (vi) la Briqueterie, or La Brique as it is called by its inhabitants (Arabic/Muslim quarter). See map in Fig. 5.

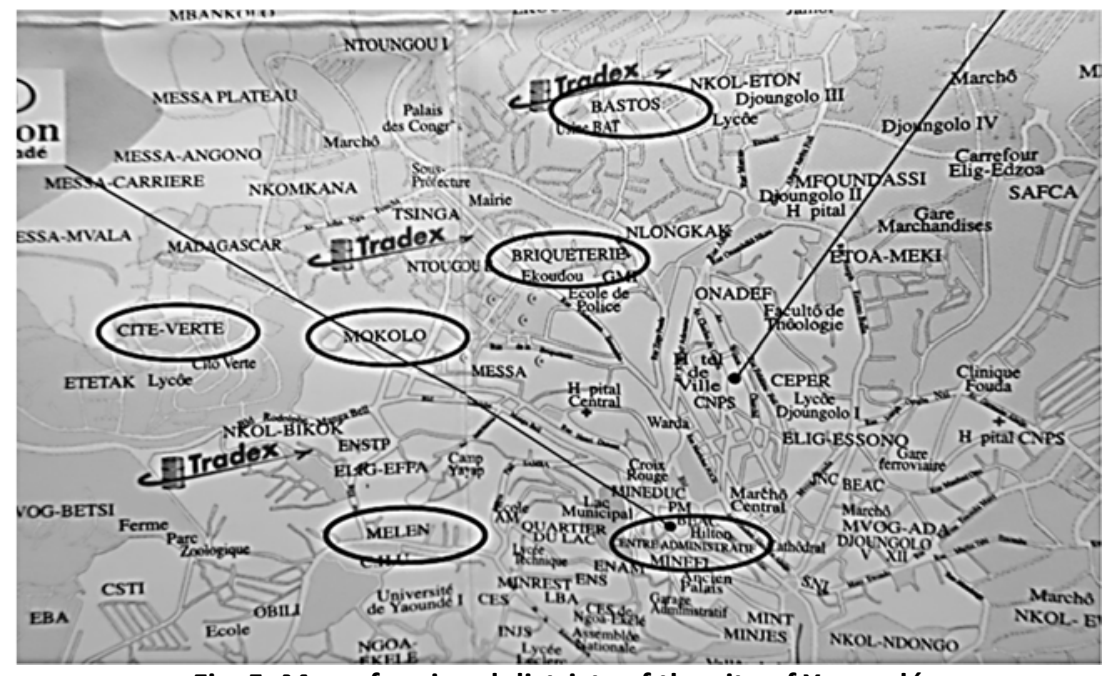

Fig. 5. Map of regional districts of the city of Yaoundé 
The following pie chart (Fig. 6) by Mundt (work-in-progress report) provides an overview of the frequency of languages on signage in Yaoundé. The overall number of signs located in Yaoundé amounted to 2,142 tokens.

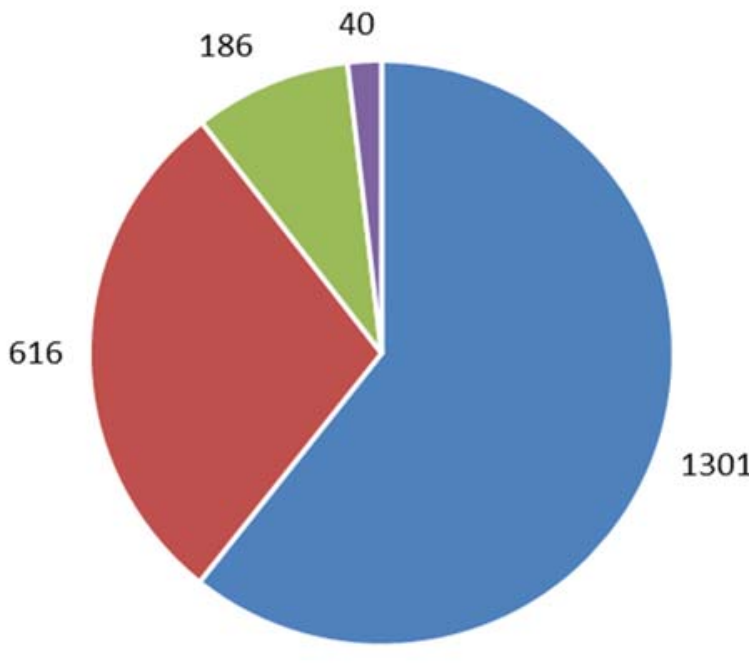

- CamF - CamF and CamE - CamE - Other

Fig. 6. Frequency of languages in the LL of Yaoundé (source: Mundt, N. work-in-progress report: preliminary results)

Naturally, CamFrench holds a dominant position $(1,301$ tokens $=60.7 \%)$ followed by CamFrench/CamEnglish bilingual signs $(616$ tokens $=28.7 \%)$, CamEnglish $(186$ tokens $=8.7 \%)$ and Other $(40$ tokens $=1.9 \%)$, with the latter including a very low amount of signage in local/African languages ( 7 tokens only $=0.3 \%$ ). In other words, the distribution of languages in Yaoundé including the dominant status of French is reflected in the LL of the capital and generally of Cameroon.

As regards representativity concerning the present study, the amount of $600+$ photos is perhaps not sufficient to adequately illustrate the overall linguistic landscape of the city of Yaoundé (2.5 million population). However, the percentages certainly provide clear tendencies of the distribution of languages in different domains such as institutions, enterprises, advertising, education, etc.

Certainly, one would assume that due to the symbolic power of the English language the Anglo-community would rather use English on linguistic tokens as part of its struggle for linguo-cultural equality. However, such signs in Yaoundé are rare $(8.7 \%)$ given the dominance and imposition of the French government and the respective reluctance of the anglophone community to demonstrate their linguistic/cultural identity (even in bottom-up signage) for fear of repercussions from the military regime. 


\subsection{The ex-colonial languages English and French in Cameroon and the fate of indigenous languages}

As mentioned above, the two official languages, English and French, joined the Cameroonian scene in 1916 when Britain and France took over Cameroon from the Germans (1886-1916). The new colonial masters then sought to impose their languages in the newly acquired territory both in the areas of education and administration. This led to the implantation of the two languages during the colonial era; a situation that was reinforced after Cameroon became independent (1960/61). At reunification in 1961, English and French became the two official languages of Cameroon as the country opted for a policy of official language bilingualism (Echu 2003).

Principally, after independence many African states granted a European language the status of an exclusive language. In most parts of Africa, the official languages have remained those of the former colonial masters, and governments have either persistently failed in attempts to revert to indigenous or national languages or have hardly thought about such initiatives. Ndille (2016: 17) rightly poses the following questions in this regard:

How did it all start, why is it that despite the multiplicity of languages in Africa, most countries ended up adopting the European language of their colonial master as official language and language of school instruction? Why is it that no indigenous language emerged even though the general tendency and cry for indigenization has been rife since independence?

This long-standing debate, which can also be phrased "Discrimination through Language in Africa?" (Pütz 1995) has been going on for decades in the continent and elsewhere. The solutions to the problem are highly complex in nature and cannot be sufficiently answered here. The dominant role of European languages as a colonial inheritance in Africa has led to linguistic inequality and serious conflict situations in sub-Saharan states. The discussion about the fate and inferior status of indigenous languages in African states reflects a high amount of language conflict, which cannot be properly understood if it is not seen in the wider context of some major philosophical and ideological currents that have been predominant in Western societies since the eighteenth century. In spite of many changes and adaptations, the two dominant cultural models, i.e., the rationalist and romantic models, are still as vigorous as ever before. Whereas the rationalist model stresses national or even global monolingualism so that every citizen can participate in the new values of Enlightenment, the romantic model stresses the identification of language and culture, and consequently sees language as a means of local, i.e. ethnic, self-expression and self-identification (Pütz \& Dirven 2007).

Today we are forced to admit that (almost) all African countries are linguistically dependent on Western Europe from which they declare themselves to be politically independent. This type of linguistic inequality has been partly caused by globalization processes and the dominant and superior status and role of ex- 
European languages during and after the state of colonization. Ugwu (2019) even goes so far as to say that "Africa is on the verge of a linguistic genocide." In her paper, she exposes the conditions of African indigenous languages and the need for actions to be taken to avert linguistic genocide in the continent.

Generally speaking, during the colonial period, language policy as exercised by the Germans (1884 - 1916), the British and the French (1916-1960/1961) in Cameroon tended to promote the languages of the colonizers to the detriment of local languages. The latter suffered severe linguistic persecution (especially by the French administration), as the various colonial administrators sought to eradicate them from the school system and generally from education. ${ }^{5}$ Regrettably, even today, indigenous languages are not finding their ways into the public school syllabus, let alone tolerated in official circles. As the LL analysis will show, this exoglossic bilingual set-up also characterizes Cameroon's LL in the sense that the great majority of signage is reflective of the ubiquity of French and, to a lesser extent, English, both in the administrative as well as the private sector.

\subsection{LL in Cameroun: Bilingual education at the University of Yaoundé}

The University of Yaoundé $I$ is the oldest state-owned university. It uses both French and English as media of instruction, but a substantial $80 \%$ of lectures are delivered in French and only 20\% in English (Echu 2004: 26). It is important to state that the university functions with a tacit bilingual language policy. The language policy of the university appears to foster bilingualism in the form of bilingual texts, i.e. saying one thing twice (Reh 2004). It is evident from the present study that most of the billboards around the Yaoundé campus and inside the university are in French, but the few that are bilingual place French in a dominant position, as can be seen in Fig. 7. French clearly dominates the signboard both in terms of color (red; not visible here) and font, as can be seen in the left-hand part of the sign.

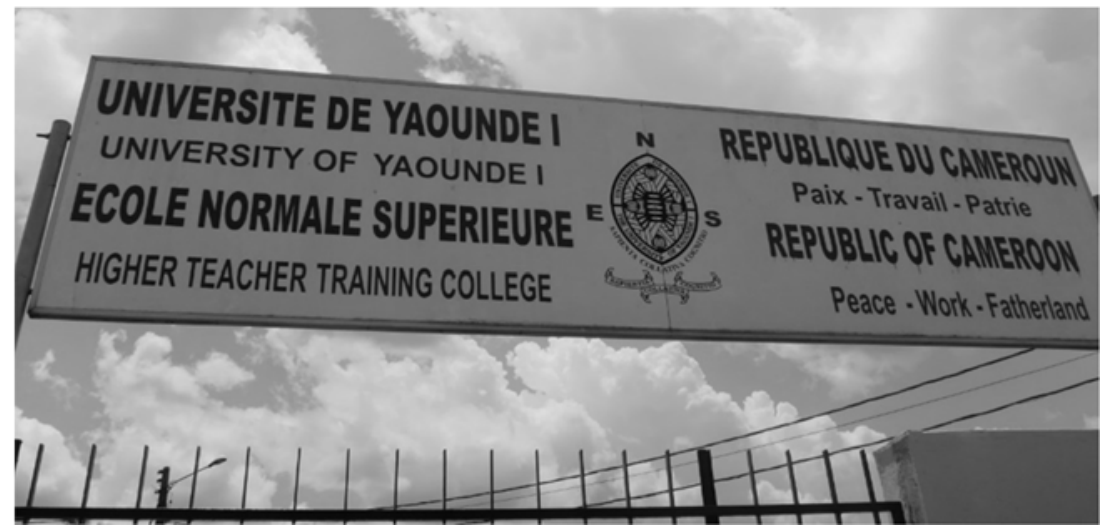

Fig. 7. University of Yaoundé (French dominance)

${ }^{5}$ Overall, Phillipson (2012) refers to the fact that French colonial education policy involved no use being made of local, indigenous languages, except to a limited extent in French Indo-China. 
As you enter the university, however, the bilingual policy completely shifts toward a uniform design, i.e. to monolingual French. This is evident in the following placards, which are found in several corners inside the university building (see Fig. 8).

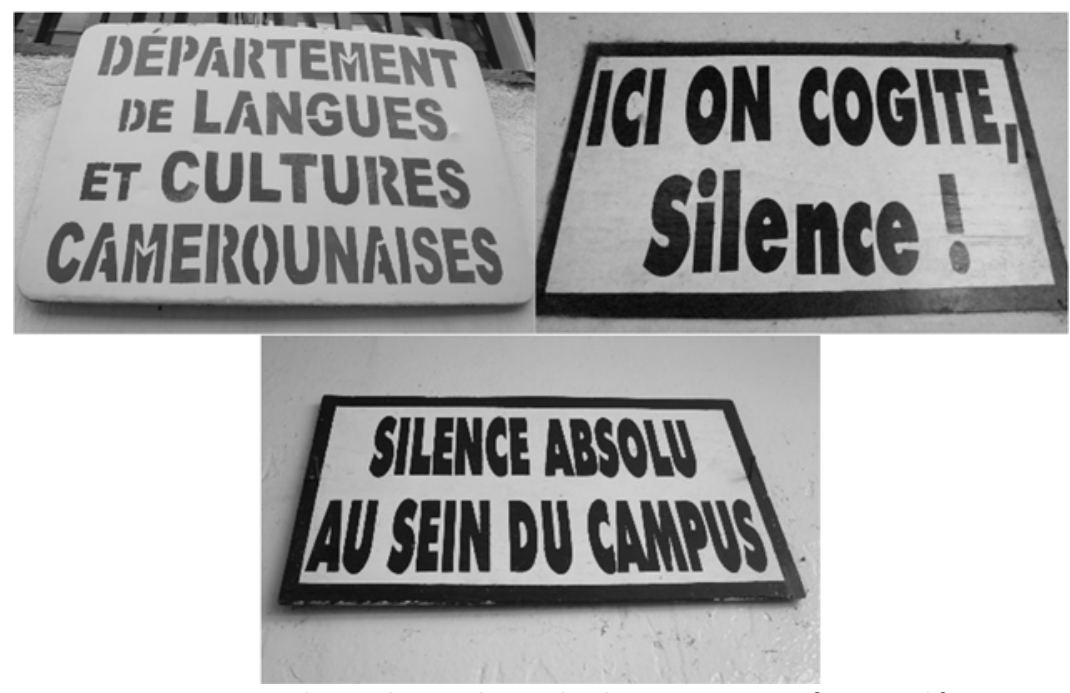

Fig. 8. Monolingual French inside the University of Yaoundé

Consequently, the LL reveals a mismatch between language policy and actual practices, and hence shows evidence of the dominant language ideologies, particularly those of the people in charge of the signage - administrators, signwriters, lecturers etc. In other words, this brings out power relations and an asymmetrical balance where the interests of anglophone speakers are not seriously taken into account. Based on the above, although the national language policy of Cameroon as well as that of the University of Yaoundé promotes official bilingualism, the situation is typified by unequal relations of power, as those in subordinate positions (English and speakers of indigenous languages) are obliged to use the language(s) of those in positions of power and authority.

Even though bilingual signs may be found in top-down signage, there is still a clear preference for French over English. This can be illustrated by way of the larger font size of the French text in bold (Universite de Yaounde I) and the (red) color (not visible here) in bold (Institut Universitaire de Technologie du Bois) as against those of English (Fig. 9).

From the perspective of a typology of multilingual writing, Reh (2004) proposes a model for describing and analyzing written texts in the LL of Uganda she doesn't use the term "linguistic landscapes" though — such as spatial mobility of the object inscribed, visibility of multilingualism and foremost a specific type of arrangement of multilingual information, which she captures in terms of duplicating, fragmentary, overlapping and complementary information. Regarding visibility, Reh (2004: 5) makes a distinction between two main types of writing: 
visible multilingualism and covert multilingualism, also referred to as multiple monolingualism.

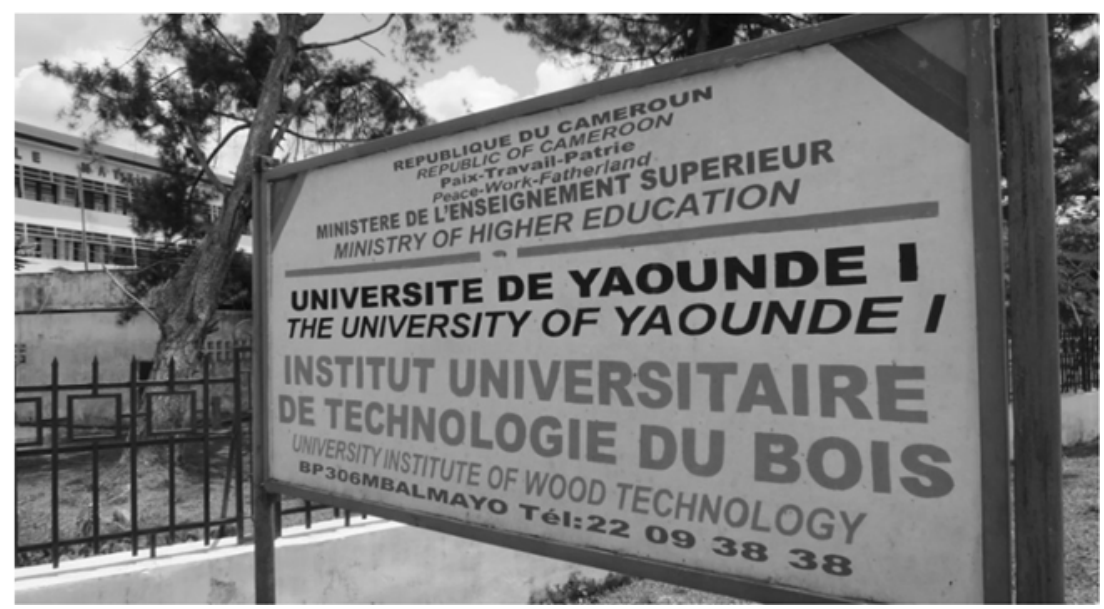

Fig. 9. Signboard of Universite de Yaoundé I / The University of Yaoundé I

Both types can be seen in Fig. 10 as illustrated by means of billboards to be found in anglophone vs. francophone Cameroon. Fig. 10, $a$ shows a social ad ("Even with HIV, she is still a friend") in front of the University of Buea and the exact translation into French (Fig. 10, b) in front of the University of Yaoundé ("Meme séropositive elle reste une amie"). This is said to be covert multilingualism since the two cities in Buea and Yaoundé are located around $320 \mathrm{~km}$ from each other. Objects are inscribed in a single language only and multilingualism arises from the fact that the text exists in other languages as well, though at some other place. Reh (2004: 5-6) observes:

The existence of covert multilingualism reflects the fact that an increasing number of texts has importance beyond just one linguistic community and that the majority of readers worldwide prefers reading texts in their most fluent typically first language, even if they have knowledge of a second.
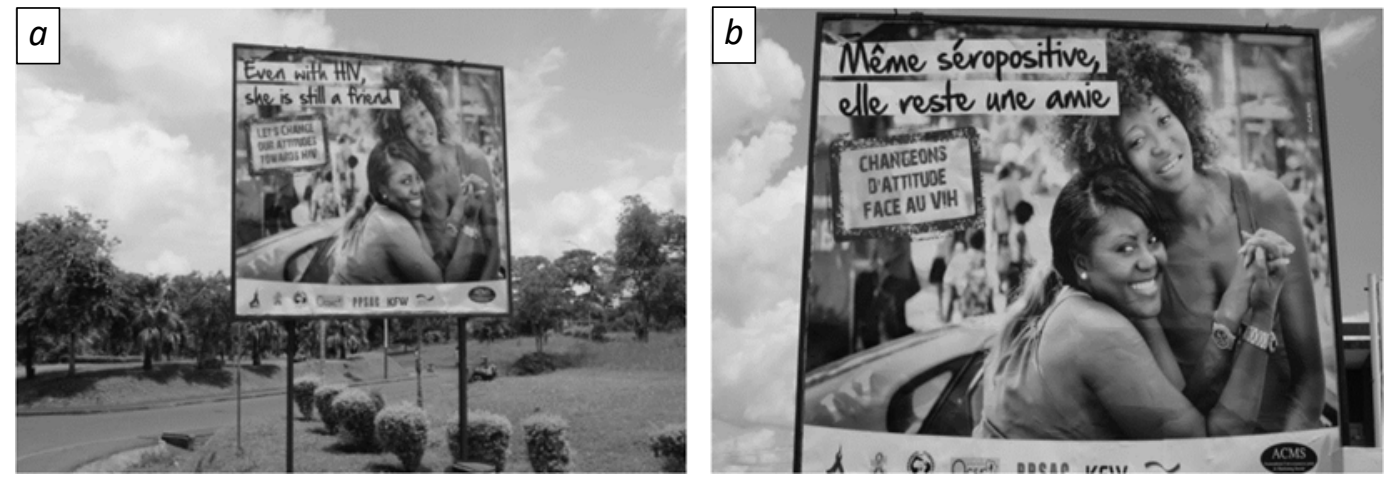

Fig. 10. Covert multilingualism: Billboards in Buea $(a)$ and Yaoundé $(b)$ 
Visible multilingualism, on the other hand, is illustrated by means of the following signage (mostly in the health domain) in Fig. 11, which shows the two languages French and English horizontally next to each other on the same billboard. So here the reader encounters the writing on the same material unit and it can be read without changing one's spatial position. Interestingly enough, there is hardly any difference in terms of font, which means that exactly the same text is presented in more than one language. Reh (2004: 8) refers to such instances using the term "duplicating multilingual writing," i.e. identical information is given in two different languages.

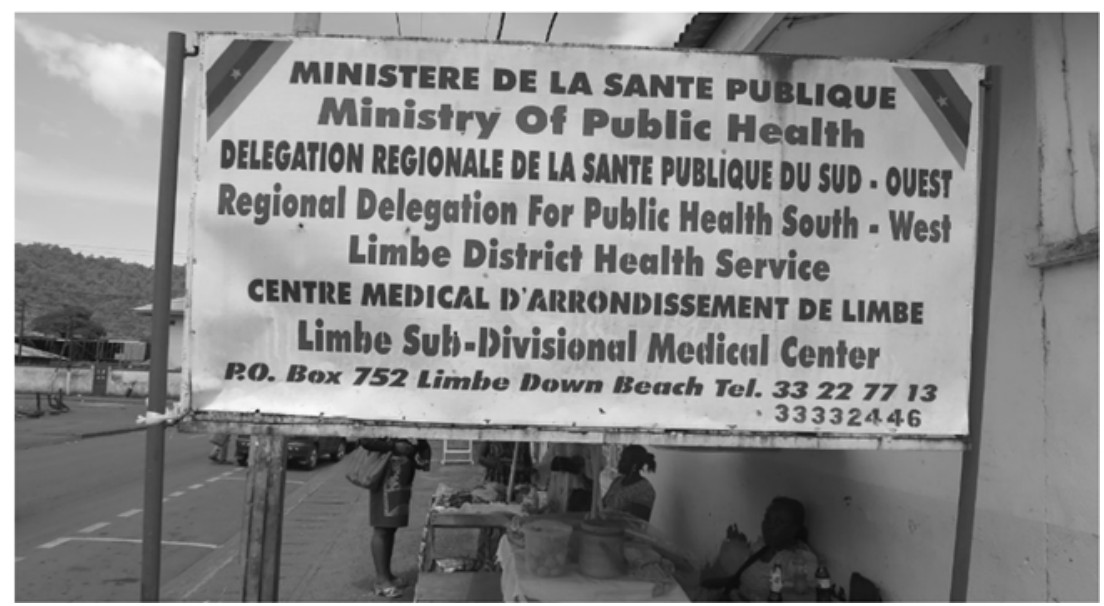

Fig. 11. Visible multilingualism (duplicating multilingual writing)

\subsection{Cameroon Pidgin English (Kamtok)}

Cameroon Pidgin English (CPE), a variety of West African Pidgin Englishes and a major lingua franca in Cameroon, is widely used not only in the anglophone regions (North-West and South-West provinces), but also in the francophone Littoral and West provinces. Presently, its influence is felt in several major towns and cities of the francophone areas such as Yaoundé and Douala. Thus, even in the francophone regions CPE has retained its strong position as a lingua franca from the early colonial days (Schneider 2007: 217). In short, CPE or Kamtok (from "Cameroon-talk"; for a discussion of the term, see Anchimbe 2013: 12) is not just a lingua franca of the English-speaking population, but a language that has a national dimension. In urban as well as rural areas, CPE is used in churches, in market places, in motor parks, in railway stations, on the streets, as well as in other informal situations. In fact, this "no man's language" is very present in the daily socio-economic lives of the people, a role it began to play as far back as the German annexation period (Echu 2003). According to Kouega (2007: 17), it is spoken by around 2 million people and is becoming a mother tongue (creolized) in some urban communities.

Still, most studies of attitudinal research in Cameroon focus on the rejection of CPE in formal and even informal settings. CPE is officially not tolerated at all in 
most educational institutions and government offices (Anchimbe 2013: 11). Moreover, the analysis of the LL in the English-speaking town of Buea shows that even on the university campus students are not permitted to converse in Pidgin. High priority is given to English as a means to communicate in the academic context whereas Pidgin is seen as a negative influence in the acquisition of Standard English. Signboards which can be found in political campaigns and on campuses such as of the University of Buea rigorously shun the use of Pidgin by the students for the reasons outlined above (see Fig. 12).

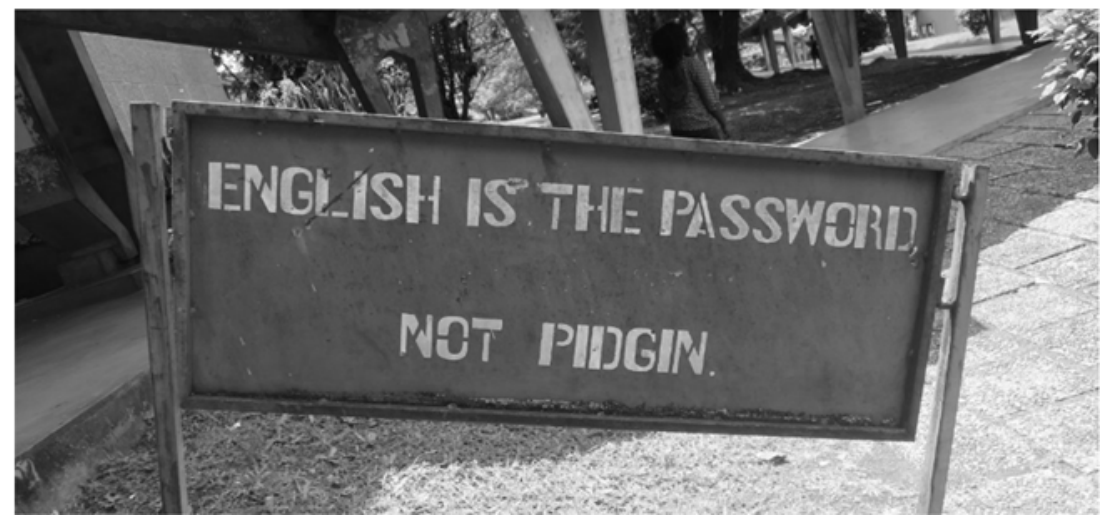

Fig. 12. Signboard shunning Pidgin English on the university campus of Buea

However, despite the negative attitudes associated with CPE, Anchimbe (2013: 12) cites scholars who are in favor of adopting CPE as the national language of the country due to being indigenous, widely understood and enjoying at least covert prestige in the country. The fact that a pidgin language entails some (covert) prestige, at least among the anglophone community mainly in the south-west and north-west, is shown by linguistic tokens implemented mainly in bottom-up (private) signage and especially in the realm of advertising and commercialization.

The following linguistic placard (Fig. 13) as a bottom-up category (private) was taken in front of a glass wall in the town of Buea (south-west Cameroon).

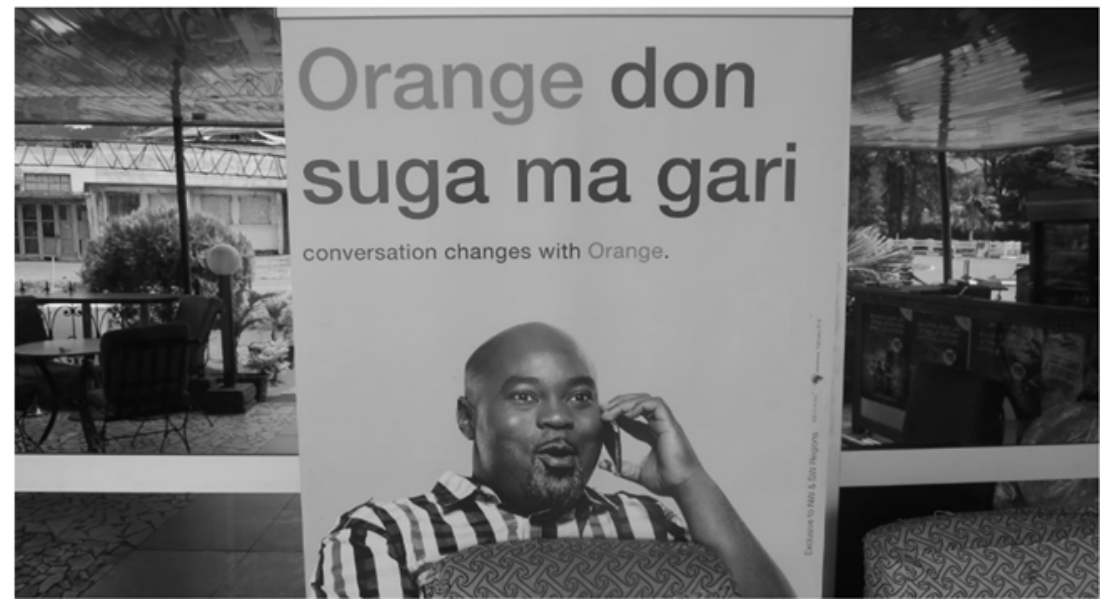

Fig. 13. Advertisement in Pidgin English, Buea 
This is an advertisement in Pidgin English provided by the telephone company Orange which, however, is a French multinational telecommunications corporation. The wording "Orange don suga ma gari" literally refers to the idea that "Orange network has put sugar in my gari" (= type of food made from cassava, i.e. a very common and easily affordable food item); in other words, "Orange" has lightened his day or made him feel comfortable.

\subsection{Camfranglais: A "created" language}

Interestingly enough, a few signs in the vicinity of Yaoundé, especially private ones (bottom-up) occasionally show monolingual inscriptions in some of the minority languages such as Chinese and Arabic as well as the two vehicular languages in the country, i.e. Pidgin English (as seen above) and Camfranglais, which Kouega (2007: 20) refers to as a "created language." The latter, also called Francanglais (Fonkoua 2015: 12), ${ }^{6}$ is most popular in the high-density urban centers (like Yaoundé and Douala) where anglophones and francophones meet on a daily basis to interact with each other. Camfranglais is a vernacular of Cameroon consisting of a mixture of Cameroon French, Cameroon English and Cameroon Pidgin English in addition to lexical contributions from various indigenous languages of Cameroon.

The vernacular first emerged in the mid-1970s after the reunification of francophone Cameroun and anglophone Southern Cameroons. Kießling (2005: 87) refers to Camfranglais as a "a highly hybrid sociolect of the urban youth type in Cameroon's big cities Yaoundé and Douala, (which) serves its adolescent speakers as an icon of 'resistance identity'." Consequently, the variety is predominantly used by youth between the ages of 12 and 26 (Stein-Kanjora 2016: 261). Moreover, although the number of female speakers is growing, the language is mainly used and developed by males, which is at least partially due to active exclusion of women by male speakers. Also, Camfranglais is considered a "secret" language, mainly used by speakers as a way to hide their conversations, or in order to appear mysterious to others. As such, it has grown rapidly within the Cameroonian secondary school system, where students use it to communicate without being understood by outsiders (Kießling 2005).

According to Simo Bobda \& Fasse Mbouya (2005), Cameroon does have cases of mixture of English and French, resulting in what is generally referred to as Franglais. In addition to these phenomena, Camfranglais has developed in Cameroon resulting from a mixture, not only of English and French, but also of Pidgin English and various local languages. The commercial billboard in Fig. 14 shows the famous Cameroonian football player Samuel Eto'o who, together with MTN (Mobile Telephone Networks), draws attention to the company by addressing the audience (or passers-by) directly. The matrix language in "switchez sur le

${ }^{6}$ Fonkoua (2015) provides a recent, updated account of the vocabulary or stock of words of Camfranglais using a lexicographic as well as an ethnographic approach to data collection by presenting a complete alphabetical lexicon of Camfranglais including its underlying etymologies. 
réseau" is French, which includes an English root (switch) attached to a French morpheme $-e z$ ( $2^{\text {nd }}$ person plural) meaning "switch on the internet". This type of code-mixing is characteristic of Camfranglais and generally of languages in contact in Cameroon; the typical speaker daily switches between three and more codes, not necessarily within one and the same word, but rather from utterance to utterance (inter-sentential switching) or speech event to speech event.

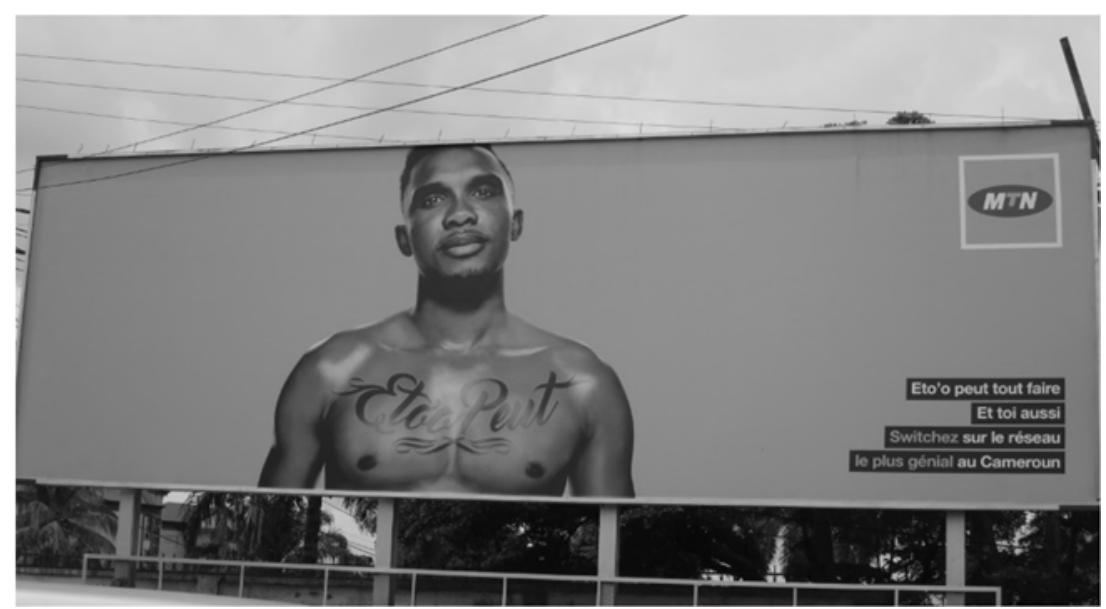

Fig. 14. Billboard showing code-mixing in Camfranglais

\subsection{Migrant languages: Chinese in Africa and Cameroon}

With the introduction of Mandarin Chinese as a foreign language in secondary and high schools in Cameroon, Chinese also plays a prominent role in Africa's LL. Makoni et al. (2012: 541) raise the question of the impact of Chinese on language policy in Africa and even hypothetically ask whether Chinese will be Africa's next lingua franca in the future. Certainly, Chinese migration is strongly connected with Cameroon's economy and its diplomatic relations with 48 African countries (Makoni et al. 2012: 541). With reference to Chinese, the perception of China as a superpower has motivated many Cameroonians to learn the language in order to be able to seize the opportunities that may become available to those who are fluent in Chinese. The example of Chinese suggests that the importance of a language, in our case, a migrant language, is directly linked to the economic and political influence of the country where it originated (Nana 2014: 34-35). It is especially so-called Confucius Institutes which are involved in the training of Chinese teachers and volunteers and which have been established through cooperation between individual universities (Makoni et al 2012: 539); likewise the Universities of Yaoundé II and Douala in Cameroon.

The following sign shows one of the numerous shops and department stores which are located at Boulevard du Président Ahmadou Ahidjo (Douala), named after the first President of Cameroon, who held office from 1960 until 1982. As Schmitt (2018) suggests, the meaning of foreign words as part of LLs may be completely irrelevant. Often the only point is to create the impression of 
foreignness. Just like in the Western world or in the African continent, in our case Cameroon, it is a common experience to find Chinese characters in and around Chinese restaurants or shops (see Fig. 15), even though hardly any of the passersby or potential customers will be able to decipher, let alone read and understand, them; the Chinese characters are merely meant to "index" Chinese culture or ways of living and to create a slightly more authentic atmosphere; in other words, they serve the idea of indexicality.

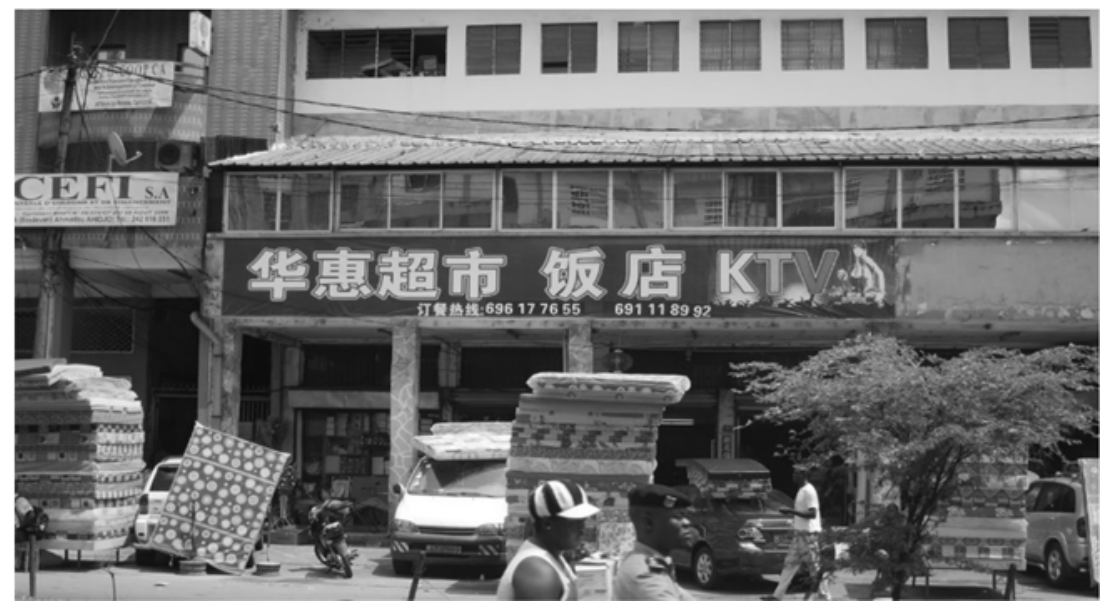

Fig. 15. Chinese shops at Boulevard du Président Ahmadou Ahidjo (Douala)

\subsection{The invisibility of indigenous languages in the linguistic landscape}

Finally, let's briefly discuss the status and role of the indigenous languages in Cameroon and see how lexical items find their way into the LL in urban and rural spaces. While quite a number of linguists deplore the current endangered state of indigenous languages in Africa, making global languages responsible for the fate of African languages (Ugwu 2019), some other researchers such as Mufwene (2016) criticize the endangered-languages movement on the grounds that language death is a natural part of the process of human cultural development and that languages die because communities stop speaking them for their own reasons.

Historically speaking, Kouega (2007) points out that during 40 years of French colonization (1920 - 1960) the indigenous languages of Cameroon were banned from use in the formal school context, and in over 40 more years of postindependence rule (1960 - 2000) the languages/varieties continued to be neglected. Accordingly, due to the alleged inferiority of their mother tongues, extremely negative attitudes on the part of their speakers, politicians and policy makers were created so that indigenous languages hardly ever found their way into the educational context or the curriculum. This negative outcome is certainly due to the fact that the two European languages, French and English, have this superordinate status in the country giving schoolchildren the opportunity to climb up the socioeconomic ladder, find jobs in the public sector and become successful in life. In a country where official usage is reserved solely for official languages, indigenous 
languages continue to be limited largely to oral usage, as well as to conversation in rural and family circles (Echu 2004).

Some local/African languages and lexical items of Pidgin English have found their way into Cameroonian English, as is evident from a study by Makoudjou (2018). This mixture of languages is due to language contact between Cameroonian English and local languages through processes of lexical borrowing. In this vein, Makoudjou shows how national identity is built and expressed through English in Cameroon. Generally, English has become increasingly localized in many parts of the world, a process which Sharifian (2017: 85) terms "global localization" or simply "glocolisation" of the language(s) involved. Makoudjou shows that Cameroonian English occasionally borrows words from local languages; such words refer mainly to culinary art (e.g. ndolé, achu and eru) and clothing (e.g. Samara, Sandja and Bubu), but also to musical instruments (e.g. mvet), folk music (e.g. Makossa) and sacred dances (e.g. Lam $=$ a dance of women performed by young girls who are about to be married), honorific titles (e.g. Tchinda $=$ Counselor of the king) and some sociocultural practices (e.g. Ashia used to express sympathy, generally used to say "I'm sorry" or "what a pity"). Regrettably, the author does not cite any examples of Cameroonian English where processes of lexical borrowing have taken place.

The present study on LL in Cameroon shows a few instances of Cameroonian English with ingredients of local/African words or phrases. Generally, however, indigenous languages are marginalized, especially in the domains of advertising and other societal domains. The following linguistic tokens are taken from the LL in Yaoundé (photographs by Neele Mundt, 2017).

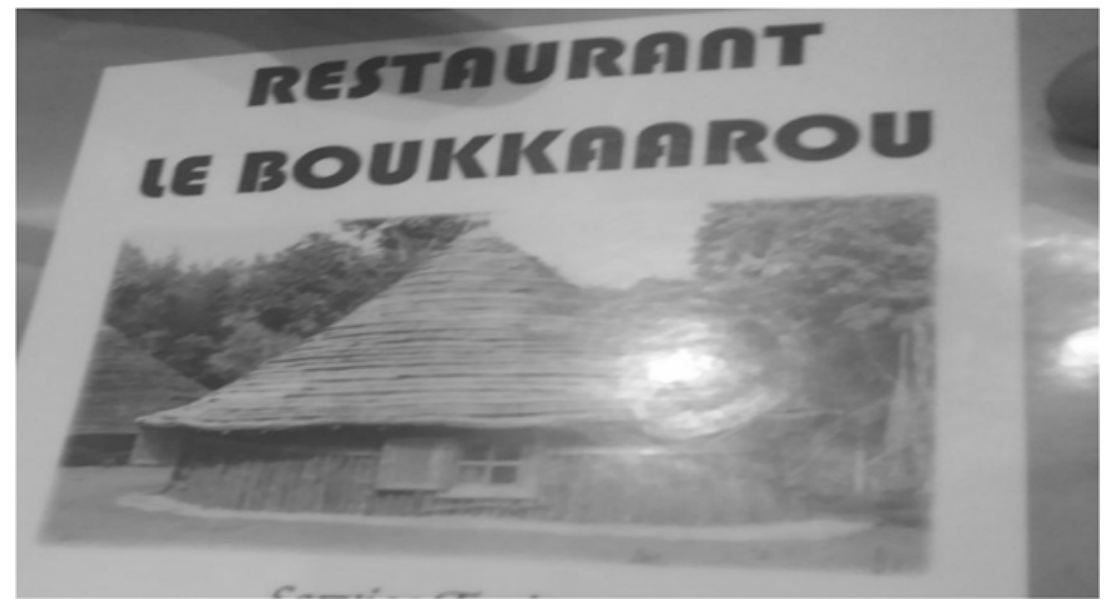

Fig. 16. Indigenous language (of Fulani origin) in bottom-up signage

Fig. 16, a poster showing "Restaurant Le Boukkaarou," is a word of Fulani origin which has been integrated into the French language. It refers to a type of thatched hut covered with hay. It resembles the "Restaurant Boukkaarou" which is here at stake. 
Concerning the word "Hakkore" in the name "Pharmacie Hakkore," this is an Ewondo lexical item meaning "to save" (Fig. 17). So, "Pharmacie Hakkore" refers to a pharmacy where people can get drugs so as to be "saved" (personal communication, Lozzi Martial Meutem Kamtchueng). The word "saved" is here used for marketing purposes.

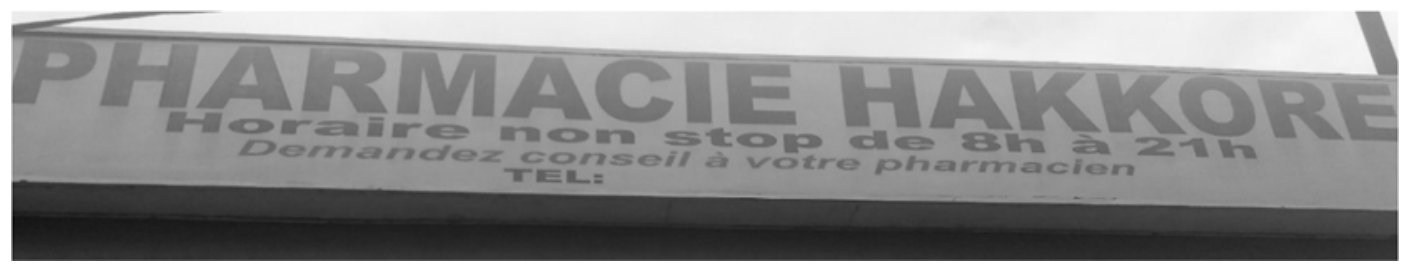

Fig. 17. Indigenous language (of Ewondo origin) in bottom-up signage

Apart from Chinese, therefore, indigenous languages in Cameroon have no visibility and play a very marginal role beyond the family, peer-group and informal domains such as the market, streets and the home. Interestingly enough, Pavlenko (2017) shows that in the past decade, also the Russian language has become one of the most popular and widely used languages in the global service industry, tourism, and marketing, alongside English and Chinese.

\section{Concluding reflections and future outlook}

Generally, the LL of the university domain reveals a mismatch between their language policy and actual practices, and hence shows evidence of the dominant language ideologies, particularly those of the people in charge of the signage: administrators, sign-writers, lecturers, etc. Although the national policy of Cameroon as well as that of the University of Yaoundé promotes official bilingualism, the situation is typified by unequal power relations, as those in subordinate positions are obliged to use the languages of those in positions of power and authority. Needless to say, local/African languages are (almost) completely absent; some of the lingua francas such as Cameroon Pidgin English and Camfranglais do not prototypically characterize the LL design. Therefore, French, as the co-official language of the country, enjoys a status not equaled by any other language/variety in Cameroon.

Future studies of Cameroon's LL should include interviews for more substantial and accurate results and also to obtain a more representative picture of the situation. With the addition of interviews, this study could be complemented in the future to show changes in the LL. Studying other neighborhoods, business centers and regional areas in the country would also lead to a more holistic and representative picture of Cameroon's LL.

As Schulte (2016) points out, LLs may also have certain drawbacks at times. For example, information on language usage in the private sphere in most cases is not sufficiently provided by the LL; also, landscapes offer only a momentary glimpse into language usage and therefore may not be "a particularly reliable and 
objective method for gathering data" (Schulte 2016: 121). Schulte's third claim that "they (LL) are not suitable to explore oral language" does not really hold since quite a number of studies have been carried out under the label of "soundscape studies" ((see, for example (Hu 2019) on a study on multilingual audio announcements in the city of Taipei, Taiwan)). These disadvantages, however, were not pertinent in the case of the present study on the LL in Cameroon given the primary interest in an investigation of languages, actors and ideology.

It is hoped that this study will contribute to a better understanding of the Cameroonian landscape and its underlying language policy issues and ideological impact, thus serving as a basis for exciting lines of future research in the study of Linguistic Landscapes.

(C) Martin Pütz, 2020 cccreative

This work is licensed under a Creative Commons Attribution 4.0 International License https://creativecommons.org/licenses/by/4.0/

\section{Acknowledgements}

I would like to thank the two anonymous reviewers of an earlier version of this paper for their valuable comments. Thanks are also due to Katie Finnegan for proofreading the manuscript and to Emma Jäger for checking the bibliography.

\section{REFERENCES}

Abongdia, Jane-Francis A. \& John Wankah Foncha. 2017. The visibility of language ideologies: The linguistic landscapes of the University of Yaoundé. Gender \& Behavior 15 (2). $8674-8680$.

Anchimbe, Eric. 2013. Language Policy and Identity Construction: The Dynamics of Cameroon's Multilingualism. Amsterdam/Philadelphia: John Benjamins.

Banda, Felix \& Hambaba Jimaima. 2015. The semiotic ecology of linguistic landscapes in rural Zambia. Journal of Sociolinguistics 19 (5). 643 - 670.

Barni, Monica \& Carla Bagna. 2010. Linguistic landscape and language vitality. In Elana Shohamy, Eliezer Ben-Rafael \& Monica Barni (eds.), Linguistic landscape in the city, 3-18. Bristol: Multilingual Matters.

Ben-Rafael, Eliezer, Elana Shohamy, Muhammad Hasan Amara \& Nira Trumper-Hecht. 2006. Linguistic landscape as symbolic construction of the public space: The case of Israel. International Journal of Multilingualism 3 (1). 7-30.

Blackwood, Robert, Elizabeth Lanza \& Hirut Woldemariam (eds.). 2016. Negotiating and Contesting Identities in Linguistic Landscapes. London/New York: Bloomsbury.

Caldwell, David. 2017. Printed t-shirts in the linguistic landscape: A reading from functional linguistics. Linguistic Landscape 3 (2). 122-148.

Coulmas, Florian. 2009. Linguistic landscaping and the seed of the public sphere. In Elana Shohamy \& Durk Gorter (eds.), Linguistic landscape: Expanding the scenery, 11-24. New York: Routledge. 
Dagenais, Diane, Danièle Moore, Cécile Sabatier, Patricia Lamarre \& Françoise Armand. 2009. Linguistic landscape and language awareness. In Elana Shohamy \& Durk Gorter (eds.), Linguistic landscape: Expanding the scenery, 253-269. New York: Routledge.

Eberhard, David M., Gary F. Simons \& Charles D. Fenning (eds.). 2019. Ethnologue: Languages of the World. $22^{\text {nd }}$ edn. Dallas, Texas: SIL International.

Echu, George. 2003. Coping with multilingualism: Trends in the evolution of language policy in Cameroon. Philologie im Netz 25. 31-46.

Echu, George. 2004. The language question in Cameroon. Linguistik Online 18 (1). 19-34.

Eko, Lyombe. 2003. The English-language press and the "Anglophone problem" in Cameroon: Group identity, culture, and the politics of nostalgia. Journal of Third World Studies XX (1). 79-102.

Fonkoua, Hector Kamdem. 2015. A Dictionary of Camfranglais. Series $<$ Duisburg Papers on Research in Language and Culture $>$. Volume 107. Frankfurt: Peter Lang.

Greene, Stephen \& Damian Williams. nd. What are linguistic landscapes? https://murbll.wordpress.com/what-is-linguisitic-landscapes/

Heller, Monica; Pujolar \& Alexandra Duchêne. 2014. Linguistic commodification in tourism. Journal of Sociolinguistics. Vol. 18, issue 4. 539-566.

$\mathrm{Hu}$, Ying-Hsueh. 2019. Multilingual audio announcements: Power and identity. In Martin Pütz \& Neele Mundt (eds.), Expanding the linguistic landscape: Linguistic diversity, multimodality and the use of space as a semiotic resource, 132 - 149. Bristol: Multilingual Matters.

Jaworski, Adam \& Crispin Thurlow (eds.). 2010. Semiotic Landscapes: Language, Image, Space. London/New York: Continuum.

Juffermans, Kasper. 2015. Local Languaging, Literacy and Multilingualism in a West African Society. Bristol: Multilingual Matters.

Kießling, Roland. 2005. 'bak mwa me do' - Camfranglais in Cameroon. Lingua Posnaniensis 47. 87-107.

Kouega, Jean-Paul. 2007. The language situation in Cameroon. Current Issues in Language Planning 8 (1). 3-94.

Landry, Rodrigue \& Richard Y. Bourhis. 1997. Linguistic landscape and ethnolinguistic vitality: An empirical study. Journal of Language and Social Psychology 16 (1). $23-49$.

Makoni, Sinfree, Busi Makoni, Ashraf Abdelhay \& Pedzisai Mashiri. 2012. Colonial and postcolonial language policies in Africa. In Bernard Spolsky (eds.), The Cambridge handbook of language policy, 523 - 543. Cambridge: Cambridge University Press.

Makoudjou, Lydie Christelle Talla. 2018. Usage of Cameroonian languages in Cameroon English. https://www.academia.edu/39735506/USAGE_OF_CAMEROONIAN_ LANGUAGES_IN_CAMEROON_ENGLISH20190702_32923_1i4̄jk90?email_work_c ard=view-paper

Makoudjou, Lydie Christelle Talla \& Solange Mekamgoum. 2019. Exploring linguistic landscape as a teaching approach to language awareness in Cameroon's secondary schools. In Pius W. Akumbu \& Esther P. Chie (eds.), Engagement with Africa: Linguistic essays in honour of Ngessimo M. Mutaka, 301-322. Series $<$ Grammatische Analysen afrikanischer Sprachen>. Band 58. Köln: Rüdiger Köppe Verlag.

McLaughlin, Fiona. 2015. Linguistic warscapes of northern Mali. Linguistic Landscape 1 (3). $213-242$.

Mooney, Annabelle \& Betsy Evans. 2019. Language, Society and Power. $5^{\text {th }}$ edn. London/New York: Routledge.

Mufwene, Salikoko. 2016. A cost-and-benefit approach to language loss. In Luna Filipović \& Martin Pütz (eds.), Endangered languages and languages in danger: Issues of 
documentation, policy, and language rights, 115-143. Amsterdam/Philadelphia: John Benjamins.

Nana, Genevoix. 2014. Medium of instruction policy and multilingual pupils' experience of learning to read and write in primary school in Cameroon. In Martin Solly \& Edith Esch (eds.), Language education and the challenges of globalization: Sociolinguistic issues, 33-66. Cambridge: Cambridge Scholars Publishing.

Ndille, Roland. 2016. English and French as official languages in Cameroon: The intentionality of colonial representations and the failure of a Cameroon-centric identity; 1884 and after. European Journal of Language Studies 3 (2). 17-33.

Nkamta, Paul Nepapleh \& Themba Lancelot Ngwenya. 2017. Linguistic inequality in Cameroon: The case of advertising in Douala. South African Journal of African Languages 37 (2). 137-147.

Pavlenko, Aneta. 2017. Linguistic landscapes and other sociolinguistic methods in the study of Russian language abroad. The Russian Journal of Linguistics 21 (3). 493-514.

Pennycook, Alastair \& Emi Otsuji. 2015. Metrolingualism: Language in the City. London/New York: Routledge.

Phillipson, Robert. 2012. Imperialism and colonialism. In Bernard Spolsky (eds.), The Cambridge handbook of language policy, 203-225. Cambridge: Cambridge University Press.

Pütz, Martin (eds.). 1995. Discrimination through Language in Africa? Perspectives on the Namibian Experience. Berlin/New York: Mouton de Gruyter.

Pütz, Martin \& René Dirven. 2007. Language conflict seen from the perspective of the rationalist and romantic models: New developments. Southern African Linguistics and Applied Language Studies 25 (3). 303-317.

Pütz, Martin \& Neele Mundt (eds). 2019a. Expanding the Linguistic Landscape: Linguistic Diversity, Multimodality and the Use of Space as a Semiotic Resource. Bristol: Multilingual Matters.

Pütz, Martin \& Neele Mundt. 2019b. Multilingualism, multimodality and methodology: Linguistic landscape research in the context of assemblages, ideologies and (in)visibility: An introduction. In Martin Pütz \& Neele Mundt (eds.), Expanding the linguistic landscape: Linguistic diversity, multimodality and the use of space as a semiotic resource, 1-24. Bristol: Multilingual Matters.

Reh, Mechthild. 2004. Multilingual writing: A reader-oriented typology — with examples from Lira Municipality (Uganda). International Journal of the Sociology of Language 170. $1-41$.

Rubdy, Rani \& Selim Ben Said (eds.). 2015. Conflict, Exclusion and Dissent in the Linguistic Landscape. Basingstoke: Palgrave Macmillan.

Schmitt, Holger. 2018. Language in the Public Space: An Introduction to the Linguistic Landscape. No publisher.

Schneider, Edgar. 2007. Postcolonial English. Varieties around the World. Cambridge: Cambridge University Press.

Schulte, Marion. 2016. Language contact and language politics in Ireland: Linguistic landscapes in South Dublin. 10plus 1: Living Linguistics 2. 118-130.

Scollon, Ron \& Suzie Wong Scollon. 2003. Discourses in Place: Language in the Material World. London/New York: Routledge.

Sharifian, Farzad. 2017. Cultural Linguistics. Cultural Conceptualisations and Language. Series <Cognitive Linguistic Studies in Cultural Contexts>. Amsterdam/Philadelphia: John Benjamins.

Shohamy, Elana \& Durk Gorter. 2009. Introduction. In Elana Shohamy \& Durk Gorter (eds.), Linguistic landscape: Expanding the scenery, 1-10. London/New York: Routledge. 
Shohamy, Elana. 2019. Linguistic landscape after a decade: An overview of themes, debates and future directions. In Martin Pütz \& Neele Mundt (eds.), Expanding the linguistic landscape: Linguistic diversity, multimodality and the use of space as a semiotic resource, 25-37. Bristol: Multilingual Matters.

Simo Bobda, Augustin \& Innocent Fasse Mbouya. 2005. Revisiting some linguistic concepts and beliefs in the light of the sociolinguistic situation of Cameroon. In James Cohen, Kara T. McAlister, Kellie Rolstad \& Jeff MacSwan (eds.), ISB4: Proceedings of the $4^{\text {th }}$ International Symposium on Bilingualism, 2122-2132. Somerville, MA: Cascadilla Press.

Spolsky, Bernard. 2009. Prolegomena to a sociolinguistic theory of public signage. In Shohamy, Elana \& Durk Gorter (eds.), Linguistic landcape: Expanding the scenery, 25-39. London/New York: Routledge.

Stein-Kanjora, Gardy. 2016. Camfrang forever! Metacommunication in and about Camfranglais. Sociolinguistic Studies 10 (1-2). 261-289.

Ugwu, Eucharia Okwudilichukwu. 2019. Africa on the verge of a linguistic genocide: The need for action. European Scientific Journal 15 (23). 57-75.

Woldemariam, Hirut \& Elizabeth Lanza. 2012. Religious wars in the linguistic landscape. In Christine Hélot, Monica Barni, Rudi Janssens \& Carla Bagna (eds.), Linguistic landscapes, multilingualism and social change, 169—184. Bern: Peter Lang.

\section{Article history:}

Received: 20 January 2020

Revised: 18 February 2020

Accepted: 15 March 2020

\section{История статьи:}

Дата поступления в редакцию: 20 января 2020

Дата принятия к печати: 15 марта 2020

\section{Bionote:}

MARTIN PÜTZ is Professor of English Linguistics at the University of Koblenz-Landau (Germany). His current research interests include multilingualism in Africa with a focus on linguistic landscapes and language policy/planning, languages in contact and applied cognitive linguistics. He has done extensive fieldwork in Australia, Cameroon, Great Britain, Namibia and South Africa, and has published around 90 articles and volumes on a variety of linguistic and sociolinguistic topics. He is the main organizer of the bi-annual International LAUD Symposia (Linguistic Agency University of Duisburg) regularly taking place at Landau, Germany. His latest book (co-edited with Neele Mundt) is in line with the present contribution and is entitled Expanding the Linguistic Landscape: Linguistic Diversity, Multimodality and the Use of Space as a Semiotic Resource published by Multilingual Matters (2019).

\section{Contact information:}

University of Koblenz-Landau (Landau campus), Germany

Im Fort 7

D-76829 Landau

e-mail: Puetz@uni-landau.de 


\section{Сведения об авторе:}

МАРТИН ПЮТЦ - профессор английского языкознания в университете КобленцЛандау (Германия). В настоящее время его научные интересы включают многоязычие в Африке с акцентом на языковые ландшафты и языковую политику / планирование и прикладную когнитивную лингвистику. Он провел обширную полевую работу в Австралии, Камеруне, Великобритании, Намибии и Южной Африке, а также опубликовал около 90 статей и книг по различным лингвистическим и социолингвистическим проблемам. Он является главным организатором Международных симпозиумов LAUD (Лингвистического агентства Университета Дуйсбурга), проводимых каждые 2 года в Ландау, Германия. Его последняя книга (в соавторстве с Нееле Мундт) соответствует теме данной статьи и называется Expanding the Linguistic Landscape: Linguistic Diversity, Multimodality and the Use of Space as a Semiotic Resource (Расширение языкового ландшафта: лингвистическое разнообразие, мультимодальность и использование пространства в качестве семиотического ресурса) (Multilingual Matters, 2019).

\section{Контактная информация:}

University of Koblenz-Landau (Landau campus), Germany

Im Fort 7

D-76829 Landau

e-mail: Puetz@uni-landau.de 